\title{
ANALISA PERHITUNGAN DAYA DUKUNG TANAH (CBR) ATAS CAMPURAN TANAH DAN S BASE 07 LIQUID SOIL STABILIZER
}

\author{
Abdullah abdulrahman ${ }^{1)}, \mathrm{S}$ Purwanto ${ }^{2)}$, Ismail ${ }^{3)}$ \\ Mahasiswa Program Studi Teknik Sipil Fakultas Teknik Universitas Palembang \\ Email : abdullahabdulrahman@gmail.com \\ Dosen Program Studi Teknik Sipil Fakultas Teknik Universitas Palembang \\ Email : ssp_3981@yahoo.co.id \\ Dosen Program Studi Teknik Sipil Fakultas Teknik Universitas Palembang \\ Email : smail64@yahoo.co.id
}

\begin{abstract}
ABSTRAK
Tanah lempung sangat dipengaruhi oleh kadar air, dalam keadaan kering mempunyai daya dukung tinggi dan kondisi keadaan jenuh akan mempunyai daya dukung rendah . Kadar air akan mempengaruhi sifat kembang susut dan parameter kuat geser tanah , permasalahan tanah lempung dimana kuat dukungnya dipengaruhi oleh kadar air , solusi alternatif yang dilakukan adalah dilakukan perbaikan tanah dengan cara stabilisasi tanah . Hasil penelitian , menurut klasifikasi unified termasuk kelompok $\mathrm{CH}$ dan menurut klasifikasi AASHTO termasuk kelompok A $-7-6$. penambahan semen atau kapur akan menyebabkan properties tanah batas cair ( LL ) menurun dengan batas plastis ( PL ) tetap sehingga indeks Plastisitas ( PI ) menurun, kemudian persentase butiran mengakibatkan jumlah fraksi halus menurun dengan gradasi lempung meningkat. Penelitian ini menganalisis perilaku tanah lempung, didapatkan kepadatan tanah maksimum dan kadar air optimum. Saat ini ada produk baru bahan stabiliser tanah yang dikenal dengan S-base 07 Liquid Soil Stabilizer menurut klasifikasinya cairan bekerja aktif pada pengujian CBR rendaman yaitu meningkatkan nilai CBR dan mereduksi pengembangan tanah. Untuk itu penelitian ini kita menggunakan S-Base 07 Liquid Soil Stabiliser 5\%, 15\% dan 25\% hasil penelitian dapat disimpulkan bahwa penambahan S-base 07 Liquid Soil Stabilizer cairan bekerja mengisi dan menyelimuti pori pori tanah sehingga meningkatkan kekedapan tanah terhadap penambahan air dan kekuatan tanah saat penjenuhan tanpa merubah sifat - sifat fisis
\end{abstract}

Kata kunci : lempung, CBR, S- Base 07 liquid soil stabiliser

\section{PENDAHULUAN}

\subsection{Latar Belakang}

Dalam pelaksanaan membangun suatu jalan seringkali dijumpai kondisi tanah yang kurang baik karena tanah dasar untuk membuat jalan memiliki sifat kohesif dan memiliki kembang susut yang tinggi yaitu mengembang pada kondisi basah dan menyusut pada waktu kering sehingga menyebabkan kerusakan pada struktur jalan yang menjadikan jalan bergelombang atau retak - retak, Ada beberapa metode stabilisasi tanah di laboratorium yaitu stabilisasi dengan kapur, stabilisasi dengan semen, stabilisasi dengan abu terbang, dan lain lain.

Metode Stabilisasi tanah lempung selalu berkembang sesuai kondisi teknologi yang terus meningkat dalam hal akademik penulis mencoba menggunakan metode bahan stabilisasi tanah khususnya dengan menggunakan campuran kimia diantaranya yaitu S- Base 07 Liquid Soil Stabilizer dimana performance kimiawi dapat mengatasi , antara lain : mengurangi plastisitas indeks , mengurangi koefisien permeabilitas serta meningkatkan kapasitas bearing tanah .

Berdasarkan Performance kimiawi tersebut penulis mencoba untuk mengkaji stabilisasi tanah lempung dengan judul :

"Analisa Perhitungan daya dukung tanah (CBR) atas campuran tanah dan S-Base 07 Liquid Soil Stabilizer" 


\subsection{Perumusan dan Batasan Masalah}

Rumusan masalah yang akan menjadi fokus pada penelitian ini adalah :untuk mengetahui daya dukung tanah ( CBR ) setelah dicampur S-base 07 Liquid Soil Stabilizer dengan beberapa persentase tanpa perendaman dan direndam selama 24 jam

Batasan masalah pada penelitian ini adalah dengan beberapa prosentase (komposisi) diantaranya :

1. Tanah ( Soil ) tanpa S-base 07 Liquid Soil Stabilizer

2. Tanah ( Soil ) penambahan S-base 07 Liquid Soil Stabilizer $5 \%$ dari berat kering tanah

3. Tanah ( Soil) penambahan S-base 07 Liquid Soil Stabilizer 15\% dari berat kering tanah

4. Tanah ( Soil ) penambahan S-base 07 Liquid Soil Stabilizer 25\% dari berat kering tanah

\subsection{Tujuan Penelitian}

Tujuan penelitian untuk mengetahui seberapa besar pengaruh pemberian S. Base 07 Liquid Soil Stabiliser dapat meningkatkaa kepadatan tanah (daya dukung tanah)

\subsection{Manfaat Penelitian}

Manfaat penelitian ini diharapkan dapat menjadi :

1. Sebagai referensi bahan $S$ Base 07 Liquid Soil Stabiliser dapat digunakan dalam konstruksi jalan terutama pada daerah daerah yeng sulit untuk mendapatkan koral dan batu pecah

2. Memberi konstribusi untuk perkembangan ilmu pengetahuan teknologi tentang bahan campuran untuk meningkatkan daya dukung tanah.

\section{TINJAUAN PUSTAKA}

\subsection{Infrastruktur}

Pemerintah Dalam periode 2014 s/d 2019 fokus pada peningkatan infrastruktur terutama jalan baik jalan bebas hambatan, jalan nasional, propinsi maupun daerah, sebagian besar jalan berhubungan dengan tanah, kondisi tanah disebagian besar wilayah Indonesia memiliki daya dukung yang rendah ini menjadi kendala dalam pembangunan konstruksi jalan, berbagai upaya dilakukan menggunkan rekayasa konstruksi untuk mengatasi hal tersebut . Diantaranya melakukan stabilisasi tanah baik mekanis maupun kimia.

\subsection{Tanah}

Tanah dalam pandangan teknik sipil, adalah himpunan mineral, bahan organik dan endapan-endapan yang relatif lepas, yang terletak diatas batuan dasar (Hardiyatmo, 2002). Sementara lempung rnerupakan akumulasi partikel mineral yang tidak mempunyai atau lemah dalam ikatan antar partikelnya yang terbentuk dari pelapukan batuan. Proses pelapukan batuan ini terjadi secara fisis atau kimiawi. Proses fisis antara lain berupa erosi tiupan angin, pengikisan oleh air dan gletser atau perpecahan akibat pembekuan dan pencairan es dalam batuan. Tanah yang terjadi oleh proses ini memiliki komposisi yang sama dengan batuan asalnya, tipe ini mempunyai ukuran partikel yang hampir sama rata dan dideskripsikan berbentuk (bulky), yaitu bentuk-bentuknya bersudut dan bulat.

Proses kimiawi menghasilkan perubahan pada susunan mineral batuan asalnya. Salah satu penyebabnya adalah air yang mengandung asam atau alkali, oksigen dan karbondioksida. Lempung merupakan salah satu bahan tanah yang mempunyai ukuran 0,002 $\mathrm{mm}$ yang lebih halus.Ada atau tidak air (selama pengeringan) dapat menghasilkan perubahan volume dan kekuatan sangat besar. Partikel-partikel lempung juga mempunyai gaya tarik antar partikel sangat kuat, yang untuk sebagian menyebabkan kekuatan sangat tinggi pada suatu bongkah yang kering (bata lempung). Penyerapan air dan tarikan antar partikel secara kolektif memberikan kegiatan dan kohesi kepada tanah yang mengandung mineral lempung.

\subsubsection{Klasifikasi Tanah}

Kegunaan klasifikasi tanah untuk mengelompokkan tanah-tanah sesuai dengan perilaku umum dari tanah pada kondisi fisis tertentu. Tanah-tanah yang dikelompokkan dalam urutan berdasarkan satu kondisi fisis tertentu bisa saja mempunyai urutan yang tidak sama jika didasarkan pada kondisi-kondisi fisis lainnya.

Oleh karena itu sejumlah klasifikasi telah dikembangkan sesuai dengan maksud 
yang diinginkan oleh sistem itu. Untuk mengetahi perlakuan tanah dasar agar dapat memenuhi persyaratan dan cukup baik sebagai pondasi jalan yang sesuai dengan spesifikasi yang ada maka perlu diketahli sifat-sifat dan klasifikasinya.

\section{Klasifikasi Tanah berdasarkan Tekstur}

Pada umumnya tanah asli merupakan campuran dari butir-butir yang mempunyai ukuran yang berbeda-beda.Tekstur tanah merupakan keadaan permukaan tanah yang diuji. Tekstur tanah dipengaruhi oleh ukuran tiap-tiap butir yang terkandung dalam tanah. Dalam sistem klasifikasi tanah berdasarkan tekstur tanah diberi nama atas dasar komponen utama yang dikandungnya, misalnya lempung berpasir (sandy clay), lempung berlanau (silty clasy) dan seterusya.

\section{Klasifikasi tanah berdasarkan USCS}

Menurut sistem ini sifat tanah ditentukan oleh ukuran butir dan gradasi butiranya.Sistem klasifikasi tanah Unifed Soil Classification System (USCS) merupakan sistem klasifikasi tanah yang paling terkenal dan pertama-tama dikembangkan di kalangan para ahli teknik tanah dan pondasi.Sistem ini lalu dipakai dengan sedikit modifikasi oleh US Bureau of Reclamation da U.S. Corps o Engineers tahun 1952.Kemudian pada tahun 1969 America Society for Testing and Materials (ASTM) telah menggunakan system Unified sebagai metode standar guna mengklasifikasikan bentuk maksud-maksud rekayasa (ASTM D-2487).

3. Klasifikasi tanah berdasarkan AASHTO

Berdasarkan system ini tanah dibagi menjadi 8 kebonipok yang diberi nama mulai dan A-1sampai dengan A-8. Kelompok A-8 merupakan kelompok tanah organik yang revisi terakhir pada sistem AASHTO diabaikan karena tanah pada kelompok ini tidak stabil sebagai bahan pelapisan perkerasan.

Pada pemakaiannya sistem klasifikasi AASHTO menggunakan data dari hasil uji dicocokkan dengan angka-angka yang diberikan dalam Tabel 2.3 dari kolom sebelah kiri ke kolom sebelah kanan ditemukan angka-angka yang sesuai.Gambar 2.2 menunjukkan suatu gambar dan senjang batas cair (liquid limit, LL) dan indeks plastisitas (P1) untuk tanah yang masuk ke dalam kelompok A2, A-4, A-5, A-6 A-7.

\subsection{Daya dukung tanah}

Daya dukung tanah adalah kemampuan tanah menahan beban yang bekerja diatasnya dalam teknik sipil beban yang bekerja bermacam macam ada bangunan, kendaraan dalam istilah disebut california bearing ratio (CBR). Tiap tip lapis tanah memiliki nilai CBR yang berbeda tergantung pada karateristik tanahnya, dan kadar air.

\section{4. $\mathrm{S}$ Base 07}

\subsubsection{Apa S-Base 07}

Salah satu keunggulan dari S-Base 07 adlah mampu menghemat biaya .Anda akan menghemat sebanyak $\pm 50 \%$ dengan menggunakan S-Base 07 ,dibandingkan dengan soil stabilizer yang lainya. Ini sekitar \pm 5 kali lebih murah per $\mathrm{m} 2$ bila dibandingkan dengan produk lainnya. Dengan harga yang sangat kompetitip ini, anda dapat membeli produk aunggulan yang memberikan pengurangan yang siknifikan dalam pemeliharaan dan perbaikan jalan. Karena pada dasarnya S-Base 07 merupakan cairan penstabil tanah/perkerasan jalan tanah yang mengandung konsentrat

\subsubsection{Karateristik S-Base 07}

Pengaplikasian S - Base 07 ramah dan aman bagi lingkungan karena S:- Base 07 bukan cairan Stabilisator seperti semen dan kapur yang cenderung sangat berdebu dan berbahaya bagi peralatan, tumbuhan, hewan dan manusia S - Base 07 secara garis besar komposisi kimia terdiri dari

- Polymer Active ingredient vinyl acrylic copolmmer $: 46 \%$

- Surfactan/Emulsifir $\quad: 2.0 \%$

- Other Special additive $\quad: 1.0 \%$

Campuran kimia S-Base 07 benar benar mencegah korosi peralatan dan tidak berbahaya pada saat diaplikasikan di jalan SBase 07 tidak memerlukan prosedur atau penangan khusus dan mudah diterapkan dengan peralatan konstruksi jalan umum

\subsubsection{Performance S-Base 07}

- S-Base 07 terdiri dari bahan material koloid yang terikat bersama sama selama proses cementation, menciptakan ukuran 
partikel yang lebih besar yang berkontribusi terhadap penurunan indek plastisitas

- S-Base 07 Mencapai tingkt maksimum viskositas, sis koloid menghasikan gel yang bersifat polymerizs. Hasilnya adalah terciptanya ikatan yang kuat dan base jalan menjadi kedap air, mencegah tindakan kapiler bercampurnya air

- Pemadatan dan pengikatan menciptakan daya dukung tanah yang lebih besar

\subsubsection{Penggunaan S-Base 07}

S-Base tidak untuk menggantikan kebutuhan aspal atau beton pada lapisan jalan .Lapisan jalan dari beton ataupun aspal juga membutuhkan struktur dasar jalan yang kuat/kokoh

Struktur dasar jalan yang dibangun dengan S-Base 07 memberikan :

- Daya dukung yang kuat/kokoh

- Lebih ekonomis, dapat tidak menggunakan lapis penutup sama sekali

- Bisa diaplikasikan untuk semua jenis tanah

- Efektif untuk konstruksi perbaikan

\subsubsection{Langkah Penggunaan S-Base 07}

- 1 Drum (200 liter/200 kg) dapat di gunakan untuk tanah atau jalan dengan luas $2000 \mathrm{~m}$ dengan panjang $1 \mathrm{~km}$ lebar 2 m ketebalan $15 \mathrm{~cm}$

- Isi tanki dengan air bersih

- Tambahkan cairan S-Base 07 ke dalam tanki air yang sudah disiapkan

- Tandai areal yang akan diolah S-Base 07

- Bongkar lapisan permukaan tanah hingga mencapai ketebalan yang diinginkan

- Gemburkan permukaan tanah dengan menggunakan alat scraper atau yang lainnya

- Siramkan campuran S-Base 07 ketanah ulangi proses hingga OCM tercapai

- Setelah OMC tercapai aduk tanah sampai rata dengan menggunkan motor grader

- Pindahkan tanah yang diolah kedua sisi area ulangi proses hingga ketebalan yang diinginkan tercapai sambail melakukan pembentukan badan jalan

- Padatkan dengan compactor $2 \mathrm{~s} / \mathrm{d} 3 \mathrm{kali}$

- Padatkan kembali dengan menggunakan Vibro hingga tanah kelihatan kering dan keras

\subsubsection{Struktur lapis perkerasan}

- Lapis tanah dasar ( sub Grade)

Lapis tanah dasar adalah lapis tanah yang berfungsi sebagai tempat perletakan lapis perkerasan dan mendukung konstruksi perkerasan jalan diatasnya

- Lapis pondasi bawah (Sub Base) Lapis pondasi bawah adalah lapis perkerasan yang terletak diatas lapis an tanah dasar dan dibawah lapisan pondasi atas

- Lapis pondasi atas (Base course)

Lapis pondasi atas adalah lapis perkerasan yang terletak diantara lapis pondasi bawah dan lapos permukaan. Dalam hal ini S-Base 07 menjadi lapis pondasi atas yang cukup kuat dan awet sehingga dapat menahan beban beban roda

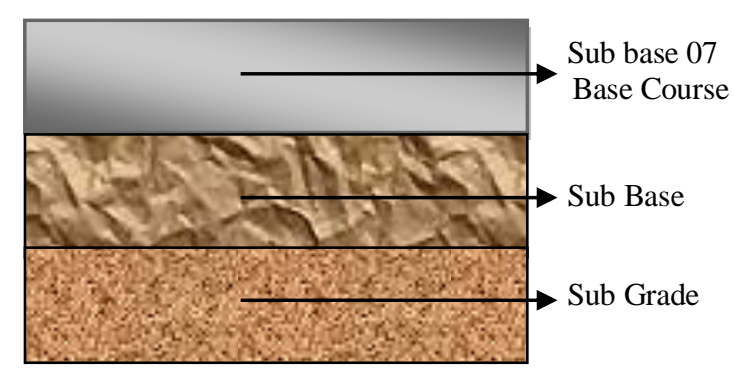




\section{METODOLOGI PENELITIAN}

\subsection{Rencana kerja penelitian}

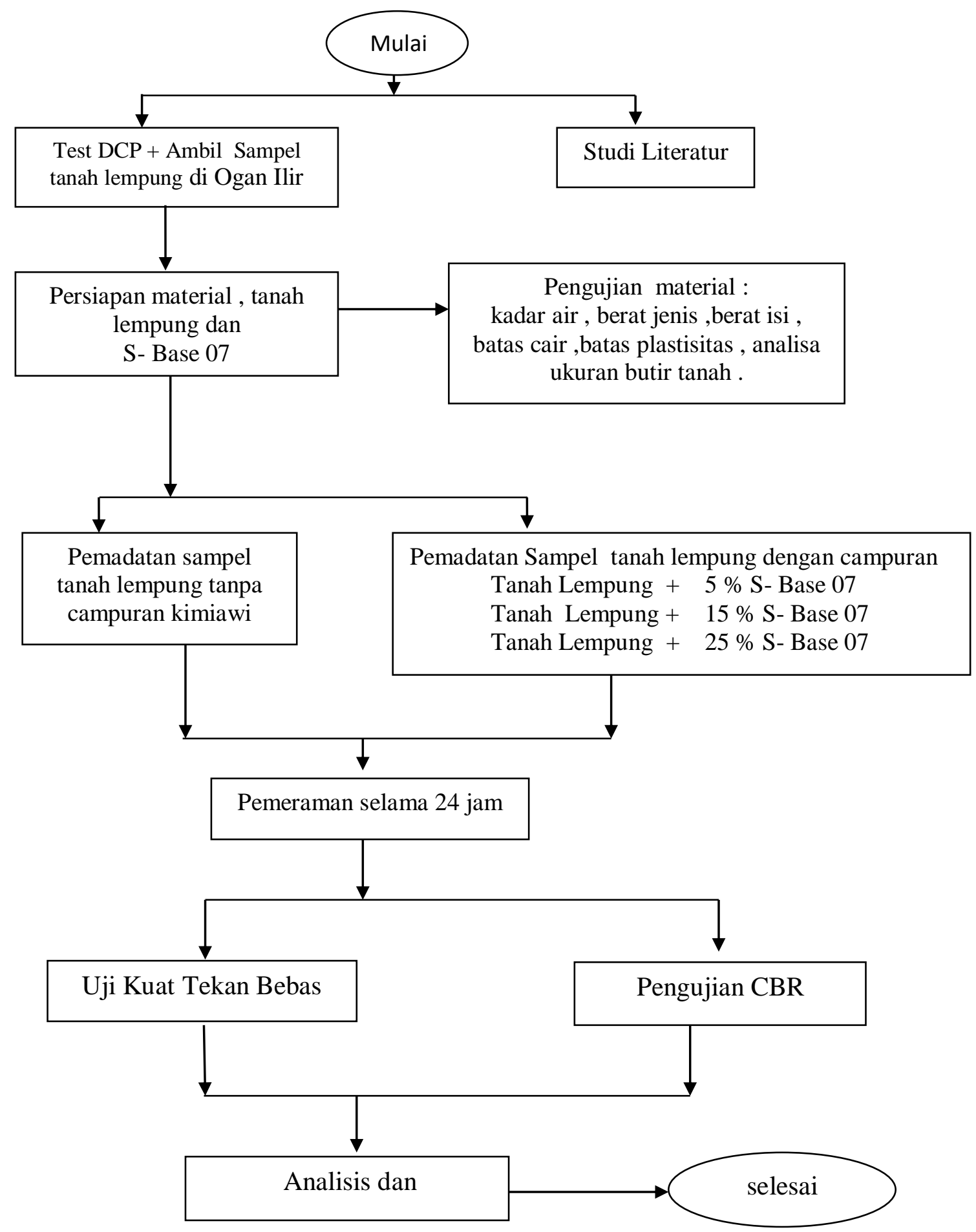

Gambar 1 . Bagan Alir Penelitian 


\subsection{Pengambilan sampel tanah}

Tanah yang akan digunakan dalam penelitian ini diambil dari Tanjung Raja Kabupaten Ogan Ilir dengan menggali tanah sedalam $1 \mathrm{~m}$ yang sebelumnya dilakukan terlebih dahulu test DCP untuk mengetahui kepadatan tanah dilokasi pengambilan sampel. Kemudian tanah dibawa kelaboratorium untuk pemeriksaan lebih lanjut. Diantaranya :

\subsubsection{Pemeriksaan sifat-sifat fisik} tanah

- Pemeriksaan Kadar Air

- Pemeriksaan berat jenis

- Pemeriksaan berat isi

- Pemeriksaan btas cair

- Pemeriksaan batas plastis

- Analisa ukuran butir tanah

\subsubsection{Pemadatan sampel tanah}

\section{lempung :}

- Tanpa campuran

Dengan capuran ( + 5\% S-Base 07, $15 \%$ S-Base 07, 25\% S-Base 07)

Melakukan perendaman selama 24 Jam

\subsubsection{Uji kuat}

- Uji kuat tekan

- Uji CBR

4. HASIL DAN PEMBAHASAN

4.1. Hasil Pengujian DCP

\begin{tabular}{|c|c|c|}
\hline Lokasi & $\begin{array}{c}\text { Jalan Belanti , Desa Siring Alam } \\
\text { Kecamatan Tanjung Raja } \\
\text { Kabupaten Ogan Ilir }\end{array}$ \\
\hline No Titik Uji & \multicolumn{2}{|c|}{ Sta 1 + 600 } \\
\hline $\begin{array}{c}\text { Pembacaan } \\
\text { Awal ( pada } \\
\text { mistar ) }\end{array}$ & \multicolumn{2}{|c|}{ 0 } \\
\hline Tanggal & \multicolumn{2}{|c|}{ 17 Pebruari 2019 } \\
\hline $\begin{array}{c}\text { Number of } \\
\text { blows ( } \\
\text { Tumbukan ) }\end{array}$ & $\begin{array}{c}\text { Cumulative of } \\
\text { blows } \\
\text { ( Kumulasi } \\
\text { jumlah } \\
\text { tumbukan ) }\end{array}$ & $\begin{array}{c}\text { Reading of } \\
\text { Penetration } \\
\text { ( Penetrasi } \\
\text { Kedalaman) } \\
\text { ( mm ) }\end{array}$ \\
\hline 0 & 0 & 0 \\
\hline 1 & 1 & 2,7 \\
\hline 1 & 2 & 4,5 \\
\hline 1 & 3 & 7 \\
\hline 1 & 4 & 9,7 \\
\hline
\end{tabular}

\begin{tabular}{|c|c|c|}
\hline 1 & 5 & 12,5 \\
\hline 1 & 6 & 14,9 \\
\hline 1 & 7 & 17,5 \\
\hline 1 & 8 & 20,5 \\
\hline 1 & 9 & 23,5 \\
\hline 1 & 9 & 23,5 \\
\hline 1 & 10 & 26,5 \\
\hline 1 & 11 & 26,5 \\
\hline 1 & 12 & 29,9 \\
\hline 1 & 13 & 33,9 \\
\hline 1 & 14 & 39 \\
\hline 1 & 15 & 44,6 \\
\hline 1 & 16 & 48,6 \\
\hline 1 & 17 & 51,8 \\
\hline 1 & 18 & 54,4 \\
\hline 1 & 19 & 57,9 \\
\hline 1 & 20 & 62,3 \\
\hline 1 & 21 & 67,1 \\
\hline 1 & 22 & 74,5 \\
\hline 1 & 23 & 83 \\
\hline
\end{tabular}

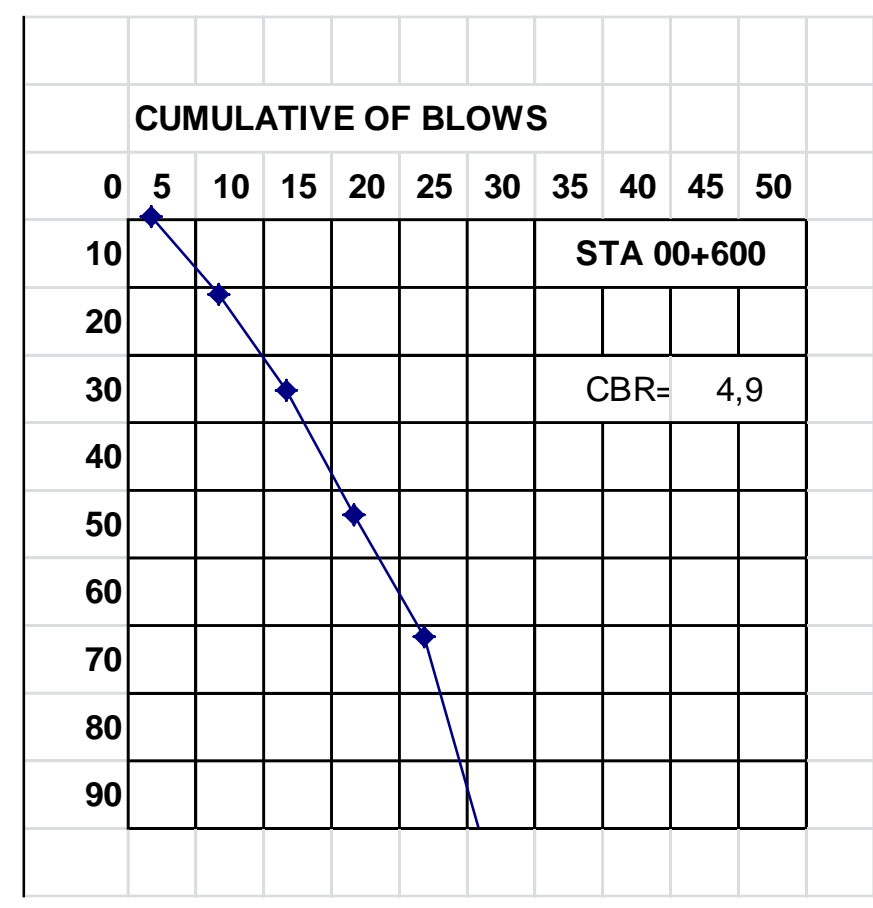

Gambar grafik 4.1 DCP

\subsubsection{Hasil Pengujian Indeks Properties Tanah Asli}

Pada pengujian Indeks Properties tanah ini dimaksudkan untuk mengidentifikasikan sampel tanah lempung ekspansif atau tidak.Dari data-data yang didapat dari pada pengujian tersebut maka dapat disimpulkan jenis tanah sampel yang ada. 
Hasil pengujian Indeks Properties tanah asli yang dilakukan, antara lain dapat dilihat pada Tabel 4.1.

Tabel 4.1 Hasil uji sifat dan mekanisme tanah asli

\begin{tabular}{|c|c|c|c|c|}
\hline & & \multirow{2}{*}{\multicolumn{3}{|c|}{$\begin{array}{l}\text { Berdasarkan hasil pengujian didapat kadar air } \\
\text { asli sebesar } 6,3 \% \text {. }\end{array}$}} \\
\hline $\begin{array}{l}\mathrm{N} \\
\mathrm{O}\end{array}$ & Data Pengamatan & & & \\
\hline 1 & Kadar Air Awal (w) & \multicolumn{3}{|c|}{$\begin{array}{l}\text { temperatur } 6,35^{\circ} \text { ( } \% \text { \%) Hasil uji Specific Gravity } \\
\text { tanah aslidan penambahan S-hase } 07 \text { Liquid }\end{array}$} \\
\hline 2 & Batas Cair (LL) & \multicolumn{3}{|c|}{ Soil Stabilobsat dilihat pada tabel 4.2. } \\
\hline 3 & Batas Plastis (PL) & \multicolumn{3}{|c|}{ Tabe24:28fifai Specific Grduity (GS) } \\
\hline 4 & Indeks Plastis (IP) & \multicolumn{3}{|c|}{$\begin{array}{c}\text { Campuran Tanah dengan S- Base } 07 \text { Liquid } \\
\text { 39,10(Soil Stabilizer } \\
\text { Soll }\end{array}$} \\
\hline 5 & Specific Grafity (GS) & NO & $\begin{array}{l}\text { be,pis Tanah + \% S- } \\
\text { Base } 07\end{array}$ & $\begin{array}{c}\text { Berat } \\
\text { Jenis (GS) }\end{array}$ \\
\hline \multirow[t]{3}{*}{6} & \multirow{3}{*}{$\begin{array}{l}\text { Butiran lolos saringan No. } 200 \\
\text { a. Lempung Tak Organik dengan } \\
\text { plastisitas tinggi } \\
\text { b. Lanau } \\
\text { c. Pasir } \\
\text { d. Kerikil }\end{array}$} & 1 & $\begin{array}{l}\text { Léa9poripg + } 0 \% \text { S- } \\
\text { Base 07 Liquid Soil } \\
\text { Stabiffzer }\end{array}$ & 2,213 \\
\hline & & 2 & $\begin{array}{l}\text { Lempung + } 5 \% \text { S- } \\
\text { Base } 07 \text { Liquid Soil } \\
\text { Stgabilizger }\end{array}$ & 2,424 \\
\hline & & 3 & $\begin{array}{l}\text { Lempung + } 15 \% \text { S- } \\
\left.\text { Base } \sigma^{\prime}\right\rangle \text { Liquid Soil }\end{array}$ & 2,648 \\
\hline \multirow[b]{2}{*}{4.1 .2} & \multirow[b]{2}{*}{$\begin{array}{l}\text { Pengujian Utama } \\
\text { Berbagai variasi campuran tanah }\end{array}$} & & Stabilizer & \\
\hline & & 4 & $\begin{array}{l}\text { Lempung }+25 \% \text { S- } \\
\text { Base } 07 \text { Liquid Soil } \\
\text { Stabilizer }\end{array}$ & 2,860 \\
\hline
\end{tabular}

mempunyai perilaku yang berbeda, tergantung persentase variasi campurannya. Dalam penelitian in variasi persentase penambahan bahan yang digunakan adalah $0 \%, 5 \%, 15 \%$ dan $25 \%$. Pengujian yang dilakukan terhadap campuran tanah dengan S-base 07 Liquid Soil Stabilizer terdiri dari uji sifat dan sifat mekanis.

Hasil uji fisis dan sifat mekanis dilihat dalam bentuk tabel dan selengkapnya akan dijelaskan dalam lampiran dan grafik berikut ini.

a. Hasil Pemadatan Proctor Pembuatan sampel untuk pengujian selanjutnya berdasarkan $\gamma_{\mathrm{d} \text { maks yaitu }} 1,60 \mathrm{gr} / \mathrm{cm}^{3}$ dengan air optimum $(\mathrm{w}$ opt $)=28,50 \%$

b. Perilaku properties tanah terhadap penambahan S- Base 07 Liquid Soil Stabilizer

Prilaku properties tanah oleh penambahanS- Base 07 Liquid Soil Stabilizer dilakukan pada uji gravitasi khusus, uji gradasi butiran, uji batas-batas atterberg tanah.

\section{Kadar air (water content)}

Merupakan perbandingan berat air yang terkandung dalam tanah dengan berat kering tanah dinyatakan dalam persen. Berdasarkan hasil pengujian didapat kadar air asli sebesar $6,3 \%$.

temperatur ${ }^{2} 5^{\circ} \mathrm{g}$. Hasil uji Specific Gravity tanah asli dan penambahan S-hase 07 Liquid

.

Tabel24,28

\section{Gradasi Butiran}

Hasil uji gradasi butiran dengan penambahan S- Base 07 Liquid Soil Stabilizer ditampilkan pada tabel 4.3

Tabel 4.3 Hasil uji gradasi butiran tanah

\begin{tabular}{|c|l|c|c|}
\hline No & $\begin{array}{l}\text { Jenis Tanah + \% S- } \\
\text { base 07 Liquid Soil } \\
\text { Stabilizer }\end{array}$ & $\begin{array}{c}\text { Fraksi } \\
\text { Halus } \\
\text { (ukuran < } \\
\mathbf{0 , 0 7 5 ~ m m ) ~}\end{array}$ & $\begin{array}{c}\text { Fraksi } \\
\text { Halus } \\
\text { (ukuran > } \\
\mathbf{0 , 0 7 5} \text { mm })\end{array}$ \\
\hline 1 & $\begin{array}{l}\text { Lempung + 0 \% S-base } \\
\text { 07 Liquid Soil } \\
\text { Stabilizer }\end{array}$ & $8,60 \%$ & $1,35 \%$ \\
\hline 2 & $\begin{array}{l}\text { Lempung + 5 \% S-base } \\
\text { 07 Liquid Soil } \\
\text { Stabilizer }\end{array}$ & $7,00 \%$ & $2,00 \%$ \\
\hline 3 & $\begin{array}{l}\text { Lempung + 15 \% S- } \\
\text { base 07 Liquid Soil } \\
\text { Stabilizer }\end{array}$ & $8,84 \%$ & $2,26 \%$ \\
\hline 4 & $\begin{array}{l}\text { Lempung + 25\% S- } \\
\text { base 07 Liquid Soil } \\
\text { Stabilizer }\end{array}$ & $7,64 \%$ & $2,36 \%$ \\
\hline
\end{tabular}




\section{Batas-batas Atterberg (Batas-batas konsistensi Tanah)}

Hasil pengujian Atterberg berupa batas cair, batas plastis dan indeks plastisitas setelah penambahan bahan additif dapat dilihat pada Tabel 4.4

Tabel 4.4 Nilai Batas-batas Atterberg (Batas Konsistensi)

\begin{tabular}{|c|l|c|c|c|}
\hline & & \multicolumn{3}{|c|}{ Batas Atterberg } \\
\cline { 3 - 5 } $\mathbf{N}$ & \multicolumn{1}{|c|}{$\begin{array}{c}\text { Jenis Tanah } \\
\text { + campuran }\end{array}$} & $\begin{array}{c}\text { Batas } \\
\text { cair } \\
\mathbf{( \% )}\end{array}$ & $\begin{array}{c}\text { Batas } \\
\text { plasti } \\
\text { s } \\
(\%)\end{array}$ & $\begin{array}{c}\text { Indeks } \\
\text { Plastisi } \\
\text { tas (\%) }\end{array}$ \\
\hline 1 & $\begin{array}{l}\text { Lempung + 0 \% } \\
\text { S-base 07 } \\
\text { Liquid Soil } \\
\text { Stabilizer }\end{array}$ & 68,78 & 39,28 & 38,50 \\
\hline 2 & $\begin{array}{l}\text { Lempung + 5 \% } \\
\text { S-base 07 } \\
\text { Liquid Soil } \\
\text { Stabilizer }\end{array}$ & 66,70 & 38,79 & 37,91 \\
\hline 3 & $\begin{array}{l}\text { Lempung + 15 } \\
\text { \% S-base 07 } \\
\text { Liquid Soil } \\
\text { Stabilizer }\end{array}$ & 64,07 & 37,12 & 46,95 \\
\hline 4 & $\begin{array}{l}\text { Lempung + 25 } \\
\text { \% S-base 07 } \\
\text { Liquid Soil } \\
\text { Stabilizer }\end{array}$ & 58,62 & 25,49 & 33,12 \\
\hline
\end{tabular}

\section{Pemadatan}

\section{Perhitungan berat isi}

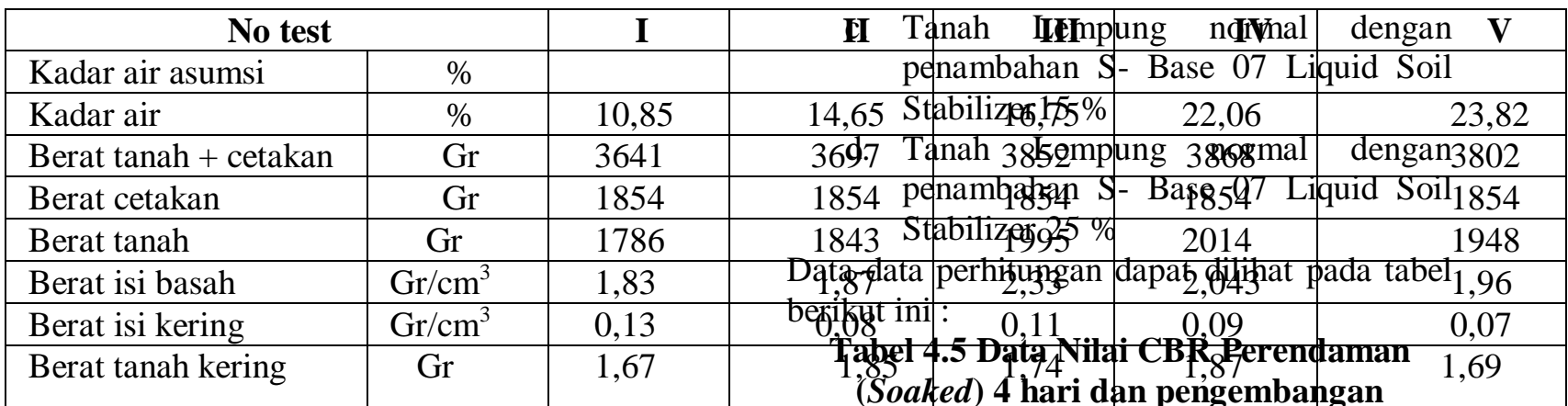

\section{Perhitungan Kadar Air}

\begin{tabular}{|c|c|c|c|c|c|}
\hline No. Cawan & $\mathbf{1}$ & $\mathbf{2}$ & $\mathbf{3}$ & $\mathbf{4}$ & $\mathbf{5}$ \\
\hline $\begin{array}{c}\text { Berat cawan } \\
\text { (gr), C1 }\end{array}$ & 15,87 & 16,29 & 16,15 & 16,13 & 16,22 \\
\hline $\begin{array}{c}\text { Berat cawan } \\
\text { + Tanah } \\
\text { basah (gr), } \\
\text { C2 }\end{array}$ & 155,29 & $\begin{array}{c}102,3 \\
142,6 \\
\text { ( } 29\end{array}$ & 125,83 & 96,95 \\
\hline $\begin{array}{c}\text { Berat cawan } \\
\text { + Tanah } \\
\text { kering (gr), } \\
\text { C3 }\end{array}$ & 141,68 & 91,39 & 124,46 & 106,00 & 81,10 \\
\hline
\end{tabular}

Analisa Perhitungan Daya Dukung Tanah (CBR) Atas Campuran Tanah dan

S Base 07 Liquid Soil Stabilizer (Abdullah abdulrahman ${ }^{\text {) }}$, S Purwanto ${ }^{2)}$ ' Ismail $^{\left.{ }^{3}\right)}$ )

\section{(Swelling)}

\begin{tabular}{|c|c|c|c|c|c|}
\hline Berat Air (gr) & 13,61 & 10,98 & 18,14 & 19,82 & 15,85 \\
\hline $\begin{array}{c}\text { Berat tanah } \\
\text { kering (gr) }\end{array}$ & 125,81 & 75,10 & 108,31 & 89,87 & 64,88 \\
\hline $\begin{array}{c}\text { Kadar Air ( } \\
\% \text { ) }\end{array}$ & 12,87 & 15,64 & 17,75 & 22,36 & 24,84 \\
\hline
\end{tabular}

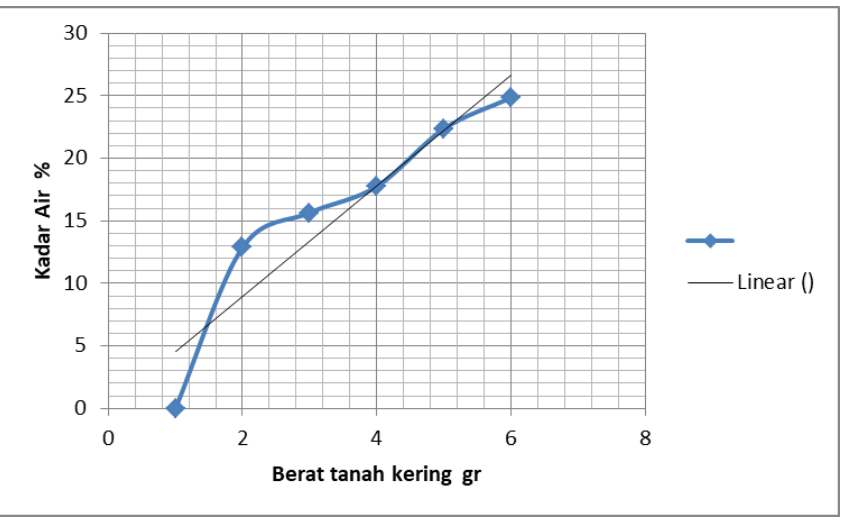

\section{Uji CBR (California Bearring Ratio)}

Pengujian ini dilakukan pada 2 kondisi yaitu CBR dengan perendaman (Soaked) dan tanpa perendaman (Unsoaked). Ada 4 variasi campuran yang dilakukan pada uji CBR Laboratorium, antara lain yaitu :

a. Tanah Lempung normal dengan penambahan S- Base 07 Liquid Soil Stabilizer

b. Tanah Lempung normal dengan penambahan S- Base 07 Liquid Soil Stabilizer $5 \%$

\begin{tabular}{|c|c|c|c|c|}
\hline \multirow{3}{*}{$\begin{array}{l}\mathrm{N} \\
\mathrm{O}\end{array}$} & \multirow{3}{*}{$\begin{array}{l}\text { Jenis Tanah }+\% \text { S- } \\
\text { Base } 07 \text { Liquid Soil } \\
\text { Stabilizer }\end{array}$} & \multicolumn{2}{|c|}{$\begin{array}{l}\text { Nilai CBR (\%) } \\
\text { Perendaman } 4 \\
\text { hari } \\
\end{array}$} & \multirow{3}{*}{$\begin{array}{c}\text { Swell } \\
\text { ing } \\
\text { Pote } \\
\text { ntial } \\
(\%)\end{array}$} \\
\hline & & \multicolumn{2}{|c|}{ Atas } & \\
\hline & & $\begin{array}{l}2,5 \\
\mathrm{~mm}\end{array}$ & $5,0 \mathrm{~mm}$ & \\
\hline 1 & $\begin{array}{l}\text { Lempung + } 0 \% \text { S- } \\
\text { base } 07 \text { Liquid Soil } \\
\text { Stabilizer }\end{array}$ & 0,193 & 3,720 & 1,62 \\
\hline 2 & $\begin{array}{l}\text { Lempung }+5 \% \text { S- } \\
\text { base } 07 \text { Liquid Soil } \\
\text { Stabilizer }\end{array}$ & 4,053 & 5,661 & 1,02 \\
\hline
\end{tabular}




\begin{tabular}{|c|l|l|l|l|}
\hline 3 & $\begin{array}{l}\text { Lempung + 15 \% } \\
\text { S-base 07 Liquid } \\
\text { Soil Stabilizer }\end{array}$ & 6,675 & 6,814 & 0,60 \\
\hline 4 & $\begin{array}{l}\text { Lempung + 25\% S- } \\
\text { base 07 Liquid Soil } \\
\text { Stabilizer }\end{array}$ & 7,297 & 7,749 & 0,08 \\
\hline
\end{tabular}

Tabel 4.6 Data Nilai CBR Tanpa

Perendaman

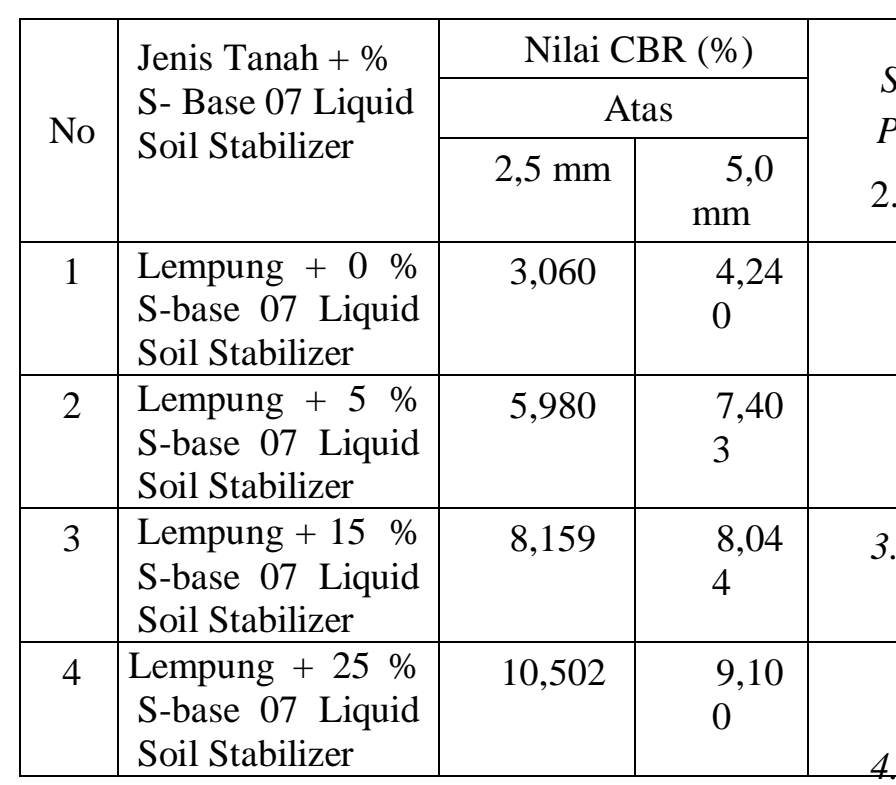

\section{Uji Tekan Bebas (Unconfined \\ Compression Test)}

Hasil Uji Tekan Bebas dengan variasi persentase dapat dilihat pada Tabel 4.7 berikut ini :

Tabel 4.7 Hasil Uji Kuat Tekan Bebas Kondisi Kering

\begin{tabular}{|c|l|c|}
\hline No & $\begin{array}{l}\text { Jenis Tanah + \% S-base 07 } \\
\text { Liquid Soil Stabilizer }\end{array}$ & $\begin{array}{c}\mathrm{Qu} \\
\left(\mathrm{kg} / \mathrm{cm}^{2}\right)\end{array}$ \\
\hline 1 & $\begin{array}{l}\text { Lempung + 0 \% S-base 07 Liquid } \\
\text { Soil Stabilizer }\end{array}$ & 6,15 \\
\hline 2 & $\begin{array}{l}\text { Lempung + 5 \% S-base 07 Liquid } \\
\text { Soil Stabilizer }\end{array}$ & 8,04 \\
\hline 3 & $\begin{array}{l}\text { Lempung + 15 \% S-base 07 } \\
\text { Liquid Soil Stabilizer }\end{array}$ & 11,45 \\
\hline 4 & $\begin{array}{l}\text { Lempung + 25 \% S-base 07 Liquid } \\
\text { Soil Stabilizer }\end{array}$ & 19,10 \\
\hline
\end{tabular}

\section{KESIMPULAN DAN SARAN}

\subsection{Kesimpulan}

Dari hasil pengujian, penelitian dan pembahasan yang dilakukan di laboratorium pada tanah lempung ekspansif asli dengan tanah lempung ekspansif campuransebesar 5\%, $15 \%$, dan 25\%S- Base 07 Liquid Soil
Stabilizer, serta dari pembahasan bab-bab sebelumnya, maka dapat disimpulkan terjadinya peningkatan, sebagai berikut :

1. Dari hasil uji tanah asli didapat nilai berat isi kering maksimum $\left(\gamma_{\mathrm{d}}\right)=1,60 \mathrm{gr} / \mathrm{cm}^{3}$; Kadar air optimum (Wopt) $=28,5 \%$; LL $=$ $68,38 \% ; \mathrm{PL}=29,28 \%, \mathrm{SL}=7,77 \%$ dan PI $=39,10 \%$, mengandung fraksi halus $96,68 \%$, dengan gravitas khusus (Gs) = 2,41. Menurut Unified Soil Classification System, termasuk kelompok $\mathrm{CH}$, sedangkan Swetipnurut American Association of State Highuay and Trasnsportation Official (AASHTO) tanah tersebut kelompok A-7-6.

2. Hasłi uji batas konsistensi (batas atterberg) campuran tanah dengan penambahan SBase $\quad 07 \quad$ Liquid $\quad$ Soil Stabilizerpersentasedibandingkan tanah asli menunjukkan batas cair (LL) mengalami penurunan dan batas plastis (PL) cenderung tetap, maka Indeks Plastisitasnya (IP) menurun.

3. PenambahanS- Base 07 Liquid Soil Stabilizer pada tanah asli menyebabkan perubahan gradasi butiran yaitu persentase fraksi halus dan fraksi kasar akan bertambah.

4. Penambahan S- Base 07 Liquid Soil Stabilizer untuk CBR perendaman (soaked) 4 hari pada tanah asli akan memperbaiki sifat mekanis tanah, yaitu menyelimuti butiran dan bekerja efektif sehingga kekuatannya meningkat dan pengembangannya (swelling) menurun. Untuk CBR tanpa perendaman (unsoaked) dengan penambahan S- Base 07 Liquid Soil Stabilizer, nilai CBR cenderung meningkat, dan mencapai titik puncak peningkatan pada penambahan sebesar $15 \%$, tetapi pada penambahan $25 \%$ cenderung mengalami penurunan.

5. Dengan penambahan persentase s/d $25 \%$ uji tekan bebas cenderung meningkat kekuatannya, hal ini dikarenakan campuran akan bekerja efektif.

\subsection{Saran}

Dari hasil kesimpulan yang telah diuraikan diatas, maka penulis mempunyai beberapa saran yang dapat dikemukakan pada pengujian stabilisasi tanah dengan material $\mathrm{S}$ Base 07 Liquid Soil Stabilizer adalah sebagai berikut ini. 
1. Pada penelitian selanjutnya stabilisasi dengan penambahan S- Base 07 Liquid Soil Stabilizer perlu diperhatikan penambahan masa perawatan dan persentase penambahan campuran

2. Dari hasil penelitian disarankan bahwa $\mathrm{S}-$ Base 07 Liquid Soil Stabilizer yang dapat dimanfaatkan secara optimum untuk perkuatan dan stabilisasi tanah lempung adalah dengan kadar penambahan Optimum $25 \%$ sehingga dapat menghasilkan perkuatan tanah dasar.

\section{DAFTAR PUSTAKA}

[1] Bowles, J.E. 1989. Sifat - sifat Fisis dan Geoteknis Tanah. Edisi Kedua Penerbit Erlangga : Jakarta.

[2] Das. Braja M. 1985 . Mekanika Tanah, Jilid I . Penerbit Erlangga : Jakarta.

[3] SNI 03 - 1738 - 1989 . Metode Pengujian CBR Lapangan

[4] SNI 03 - 1744 - 1989. Metode Pengujian CBR Laboratorium.

[5] Harry Cristiady Hardiyatmo . 1996. Mekanika Tanah I . Penerbit Universitas Gajah Mada : Yogyakarta.

[6] Syahrudin S., Arie . jurnal aptek vol 2 no1 Juli 2010 , Pengujian Daya Dukung Perkerasan jalan dengan Dynamic Cone Penetrometer ( DCP ) Sebagai Standar untuk Evaluasi Perkerasan Jalan.

[7] Rama Indera Kusuma1), Enden Mina2), Rudy Bonar O M3) Stabilisasi Tanah Lempung Dengan Menggunakan Abu Sawit Terhadap Nilai Kuat Tekan Bebas. ( Studi Kasus Jalan Desa Cibeulah, Pandeglang ). 